\title{
Richness of plants, birds and mammals under the canopy of Ramorinoa girolae, an endemic and vulnerable desert tree species
}

\author{
Riqueza de plantas, aves y mamíferos bajo el dosel de Ramorinoa girolae, \\ una especie arbórea endémica y vulnerable del desierto
}

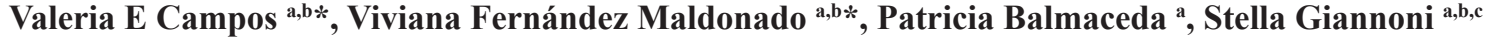 \\ a Interacciones Biológicas del Desierto (INTERBIODES), Av. I. de la Roza 590 (O), J5402DCS Rivadavia, San Juan, Argentina. \\ *Corresponding author: ${ }^{b}$ CIGEOBIO, UNSJ CONICET, Universidad Nacional de San Juan- CUIM, Av. I. de la Roza 590 (O), \\ J5402DCS Rivadavia, San Juan, Argentina, phone 0054-0264-4260353 int. 402, vcampos@unsj-cuim.edu.ar, \\ vivifernandezm@unsj-cuim.edu.ar \\ c IMCN, FCEFN, Universidad Nacional de San Juan- España 400 (N), 5400 Capital, San Juan, Argentina.
}

\begin{abstract}
SUMMARY
Dominant woody vegetation in arid ecosystems supports different species of plants and animals largely dependent on the existence of these habitats for their survival. The chica (Ramorinoa girolae) is a woody leguminous tree endemic to central-western Argentina and categorized as vulnerable. We evaluated 1) richness of plants, birds and mammals associated with the habitat under its canopy, 2) whether richness is related to the morphological attributes and to the features of the habitat under its canopy, and 3) behavior displayed by birds and mammals. We recorded presence/absence of plants under the canopy of 19 trees in Ischigualasto Provincial Park. Moreover, we recorded abundance of birds and mammals and signs of mammal activity using camera traps. Our camera traps captured more than 80,90 and $50 \%$ of plants, birds and mammals, respectively. The coverage estimate was $83 \%$ for birds and $89 \%$ for mammals. Bird species richness decreased by $-43 \%$, for every unit increase in number of stems; although richness of plants and mammals was not explained by any variable considered. Birds and mammal species invested more time in foraging than they did in moving or resting under canopies. The abundance of South American gray fox (Lycalopex griseus) increased $9 \%$ with abundance of birds, though not with abundance of mammals. This is the first study to assess the role of $R$. girolae in the provision of biodiversityrelated ecosystem services; a relevant aspect because their conservation can enhance biodiversity in arid ecosystems.
\end{abstract}

Key words: biological interactions, arid ecosystem, species richness, habitat, Ramorinoa girolae.

\section{RESUMEN}

Los bosques de ecosistemas áridos mantienen plantas y animales que dependen de la existencia de estos hábitats para su supervivencia. La chica (Ramorinoa girolae) es una leguminosa leñosa endémica del centro-oeste de Argentina y categorizada como vulnerable. Se evaluó 1) riqueza de plantas, aves y mamíferos asociados al hábitat bajo su dosel, 2) si la riqueza está relacionada con atributos morfológicos y con características del hábitat bajo su dosel, y 3) el comportamiento desplegado por aves y mamíferos. Se registró la presencia/ausencia de especies vegetales bajo el dosel de 19 árboles en el Parque Provincial Ischigualasto. Se observó la abundancia de aves y mamíferos usando trampas cámara, y signos de actividad de mamíferos. Se capturó más del 80, 90 y $50 \%$ de las especies de plantas, aves y mamíferos, respectivamente. La cobertura estimada fue $83 \%$ para aves y $89 \%$ para mamíferos. La riqueza de aves disminuyó en -43 \% por cada incremento en el número de ramas, pero la riqueza de plantas y mamíferos no fue explicada por ninguna variable. Tanto aves como mamíferos invirtieron más tiempo en forrajear que en desplazarse o descansar bajo el dosel. La abundancia del zorro gris sudamericano (Lycalopex griseus) aumentó $9 \%$ cuando aumentó la abundancia de aves pero no la de mamíferos. Este es el primer estudio que evalúa el rol de $R$. girolae en la prestación de servicios relacionados con la biodiversidad; un aspecto relevante ya que su conservación puede mejorar la biodiversidad en los ecosistemas áridos.

Palabras clave: interacciones biológicas, ecosistema árido, riqueza de especies, hábitat, Ramorinoa girolae.

\section{INTRODUCTION}

An arid environment has extreme weather conditions (e.g. high temperature and radiation), poorly developed soils, scarce food and water resources, heterogeneously available both in space and time. These harsh environ- mental conditions determine the presence of specifically adapted biodiversity, with a high number of endemic species and of species of conservation concern (Costa 1995). Owing to these causes, arid environments and their services have high ecological value (MEA 2005). The dominant woody plants inhabiting arid ecosystems are likely to cau- 
se changes in microclimate and soil properties under their canopies, generating gradients that increase spatial heterogeneity and provide microhabitats for high diversity of plants (Rossi and Villagra 2003) and associated animals.

Globally, ecosystems, habitats and species continue to disappear, and lost with them are ecosystem services. Biodiversity is an important factor in ecosystem functioning and in the provision of many ecosystem goods and services. Because woodlands are vitally important as habitats for a major part of the world's biodiversity, their ongoing loss, fragmentation and degradation cause much concern about the resulting decline in biodiversity, which is likely to have far-reaching consequences (see review Brockerhoff et al. 2013). Included among the latter are biomass loss, global warming, changes in hydrological regimes, reduced water holding and infiltration capacity, increased soil erosion and sedimentation, landscape fragmentation, increased wildlife migration and poaching (Thompson 2011).

Biodiversity is the foundation of ecosystem services to which human well-being is intimately linked (MEA 2005), where biological interactions are nodes crucial to communities and key factors in ecosystem functioning (García et al. 2011). Chica (Ramorinoa girolae Speg.) is a plant of special interest to conservation given its provision of biodiversity-related ecosystem services in arid ecosystems. Ramorinoa girolae is a woody leguminous tree (Fabaceae), leafless though with green stems, whose individuals are on average $4 \mathrm{~m}$ tall (Hadad et al. 2014). It is a species endemic to central-western Argentina and its morphological features enable it to maintain different biological interactions. Its fruits are woody and very hard, and contain between one and five seeds of high nutritive value ( $21.2 \%$ proteins and $29.3 \%$ lipids, Zapata et al. 2010). Its seeds are consumed by the viscacha rat (Octomys mimax Thomas), a rock-dwelling rodent endemic to western Argentina that pierces the fruit to extract the seeds (Campos 2012). This rodent hoards the harvested fruits in fairly large quantities over time, probably depending on the sporadic and massive fruiting of the $R$. girolae (Campos 2012). Recent studies show that one species of moth (Anypsipyla univitella Dyar) is the only pre-dispersal seed predator (Papú 2014). Associated with this moth there is a parasitic wasp (Goniozus sp. Förster) that attacks immature stages of Coleoptera and Lepidoptera (Papú 2014). Moreover, spiders use fruit cavities left by larvae of $A$. univitella as shelters to lay their eggs, while ants (Camponotus punctulatus Mayr) feed on remains of seeds or fruits (Papú 2014). Furthermore, $R$. girolae provides other ecological services because its decumbent stems and radicular system allow stabilizing watersheds and sandstones of the mountains where it grows, thus decreasing soil erosion by water and wind. In some individuals, their buried stems are able to produce new individuals by agamic reproduction. Loca1ly, it is considered an appreciated forest resource owing to its fruits and timber (one of the hardest woods of the country). Owing to its restricted geographic distribution, slow growth and low fire resistance, this species was categorized as vulnerable. Currently, it is being assessed for inclusion in the "endangered" category according to the International Union for Conservation of Nature (IUCN 2001, Hadad et al. 2014).

Since desert woody plants are likely to cause changes in microclimate and soil properties, generating gradients that increase spatial heterogeneity and provide microhabitats and food resources, we expect that the morphological traits of $R$. girolae will explain the richness of plants, birds and mammals associated with the habitat beneath their canopies. In this work, we evaluate 1) richness of plants, birds and mammals under $R$. girolae canopy, 2) whether richness of plants, birds and mammals is related to the morphological attributes of $R$. girolae and to the features of the habitat under its canopy, and 3) behavior displayed by birds and mammals under the canopy of $R$. girolae.

\section{METHODS}

Study area. The study was conducted in Ischigualasto Provincial Park, San Juan Province, Argentina (figure 1). The Park has an area of 62,916 ha and lies on a hyper-arid sector of the Monte Desert, which corresponds to the center of the Monte de Sierras y Bolsones. Its average annual precipitation is $100 \mathrm{~mm}$ (Labraga and Villalba 2009). The area is characterized by a wide temperature range throughout the year; mean annual temperature is $22{ }^{\circ} \mathrm{C}$, with a maximum of $45{ }^{\circ} \mathrm{C}$ and a minimum of $-10{ }^{\circ} \mathrm{C}$. The study area is dominated by rocky outcrops of sandstones with varying salt content; moreover, there are areas of fine-textured substrata (sands and clays) where water accumulates after a rainfall event (Márquez et al. 2005). The vegetation is xerophytic due to the low rainfall and high temperatures, and its cover is heterogeneous, ranging from 5 to $80 \%$ (Márquez et al. 2005).

Field survey. We selected 19 individuals of $R$. girolae (figure 2) of a minimum height of $3 \mathrm{~m}$, separated from each other by at least $100 \mathrm{~m}$, at two sites occupied by the species (Campos et al. 2016) and topographically accessible in Ischigualasto Provincial Park (Site 1: $\mathrm{N}=10$ and Site 2: $\mathrm{N}=9$, figure 1). To evaluate plant richness, we recorded presence/absence of plant species all over the area beneath the canopy of $R$. girolae. The sampled area under each $R$. girolae changed according to size of each individual tree. To evaluate richness of birds and mammals, we placed camera traps (Primos Truth Cam Ultra 46 Camera) under the canopy of each $R$. girolae. These cameras are equipped with infrared (PIR) motion sensor, which detects motion and the difference between body heat and outdoor temperature. It has a detection angle of 43 degrees, an infrared flash range of $14 \mathrm{~m}$ and a detection range of $15 \mathrm{~m}$. As daylight transitions back-and-forth between light and dark, the camera changes settings to optimize the picture. 


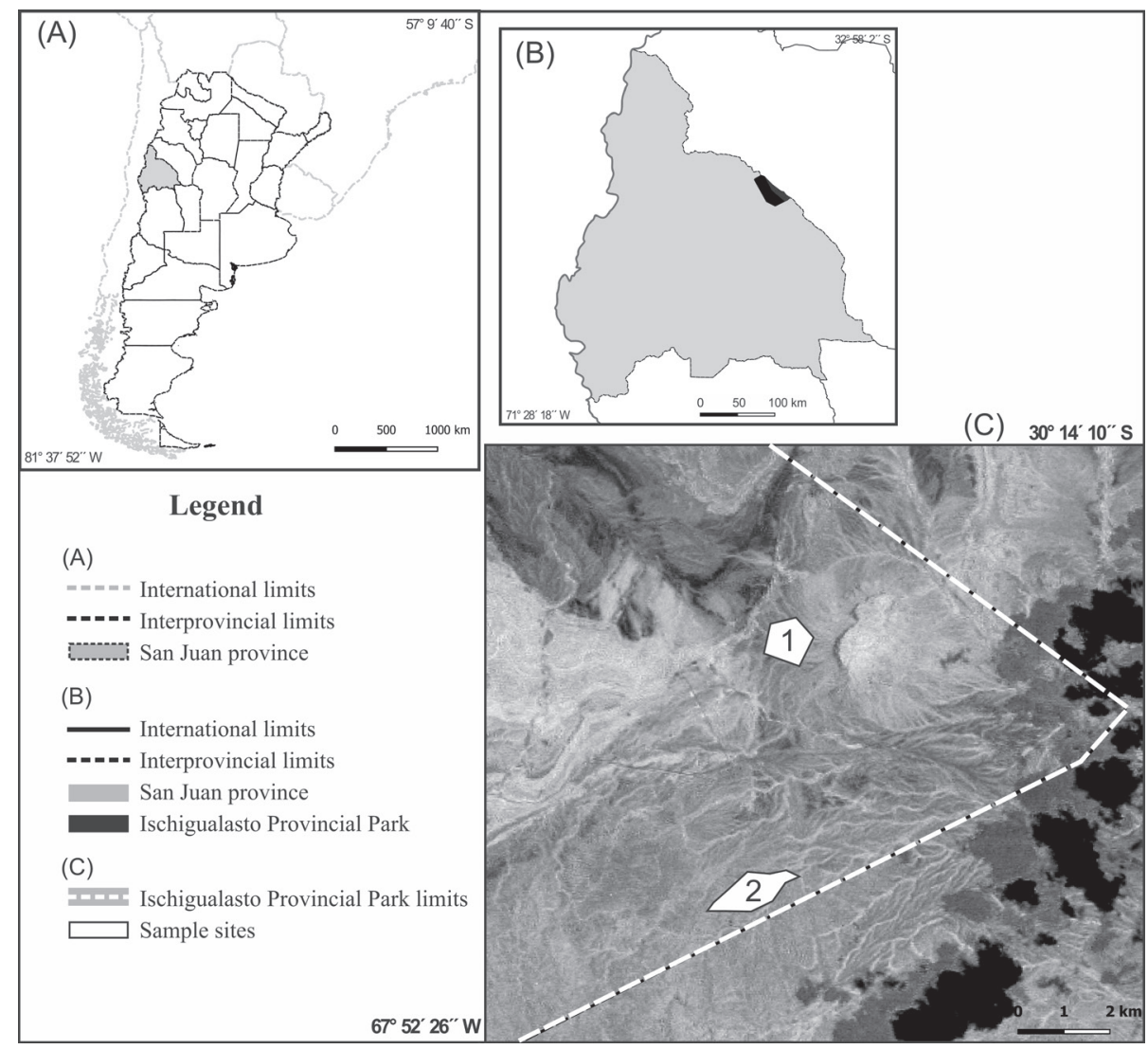

Figure 1. (A) San Juan province in South America, (B) Ischigualasto Provincial Park in San Juan province and (C) Sample sites in Ischigualasto Provincial Park.

(A) Provincia de San Juan en Sudamérica, (B) Parque Provincial Ischigualasto en la provincia de San Juan y (C) sitios de muestreo (1 y 2) en el Parque Provincial Ischigualasto.

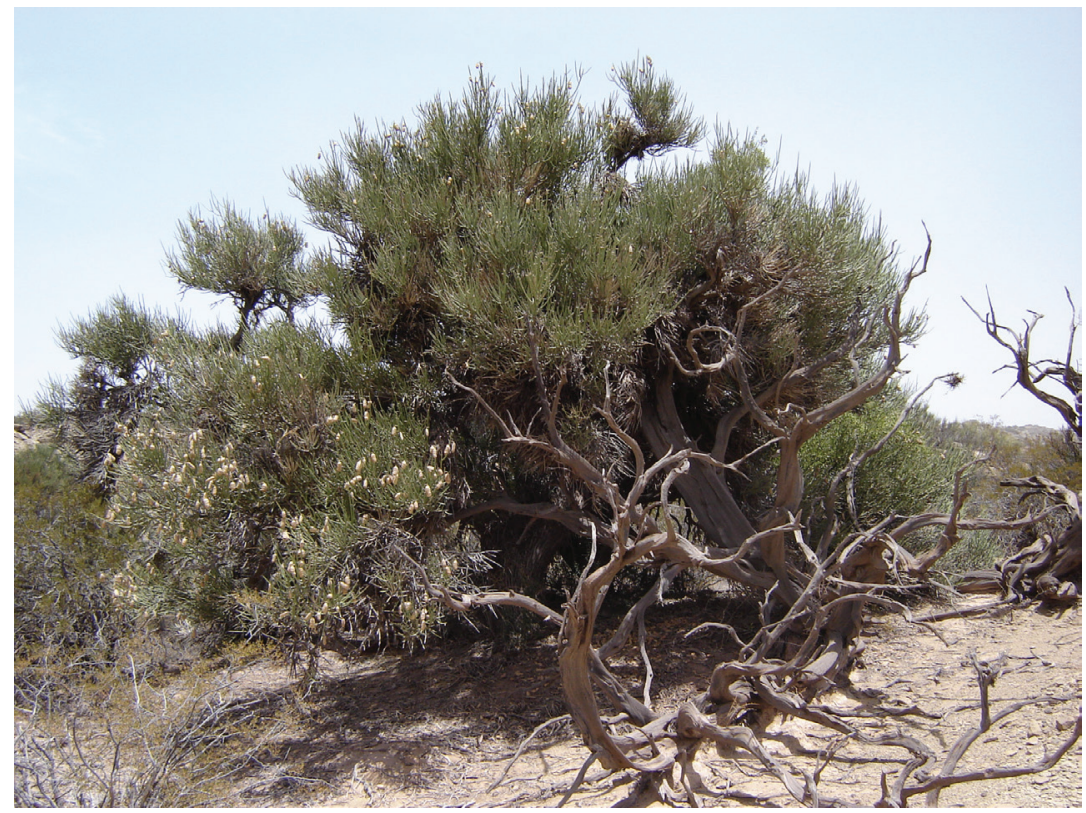

Figure 2. Individual of $R$. girolae in the Ischigualasto Provincial Park.

Individuo de Ramorinoa girolae en el Parque Provincial Ischigualasto. 
Sampling was performed over a 17-day period in the wet season (March 2013), hence the sampling effort was 7,752 hours per days and per camera traps. We sampled during the last month of the wet season because plant species grow in response to rains and in this particular year the heaviest rains were in February. Moreover, this is the breeding season of birds in this area. Each camera trap was fastened to the thickest stem at $0.50 \mathrm{~m}$ height, therefore it could cover about $25 \%$ of the total canopy area. We recorded animal behavior on 30 -second duration videos $(640 \times 480$ resolution) and considered different individuals when videos of the same species recorded by the same camera trap were separated by $30 \mathrm{~min}$. Moreover, we recorded signs of mammals (e.g. feces, footprints, caches of plant material) before placing camera traps, to determine presence/absence of their species under and $2 \mathrm{~m}$ around the canopy of $R$. girolae. To identify species of plants, birds and mammals, we used different guides and consulted with specialists.

For the second objective, we recorded morphological attributes of $R$. girolae: 1) number of stems arising from the main trunk, 2) maximum height (m), 3) canopy area $\left(\mathrm{m}^{2}\right)$, and 4) features of the habitat under its canopy: 4.1) cover of shrubs (percentage) and 4.2) cover of herbs (percentage). The cover of shrubs and herbs was estimated visually on the area under the canopy, which changed according to size of each individual. For the last objective, we considered proportions (duration of behavior in seconds/ video length in seconds) of different behaviors (Martin and Bateson 1993). Behaviors were defined as follows: 1) foraging, when animals were with head down; 2) resting, when animals were lying or sitting; 3) moving, when animals were walking with their heads up.

Statistical analyses. For the first objective, we used EstimateS (version 9.1) software (Colwell 2011) to obtain estimates of species richness. Because for mammals we had data from the camera traps and records of signs, we considered only occurrence of species rather than abundance of species. The estimators used were Chao 1, Chao 2, Jackknife 1 and Jackknife 2, according to data type (occurrence for plants and mammals, and abundance for birds). As a measure of sample completeness for plants, birds and mammals, we estimated the sample coverage and coverage-based rarefaction and extrapolation curves with $95 \%$ confidence intervals.

For the second objective, we adjusted models with different response variables: 1) plant richness, 2) bird richness, and 3) mammal richness. We included morphological attributes of $R$. girolae as a fixed variable for all models. For birds and mammal richnes, we added features of the habitat under its canopy. Data were not transformed or standardized. We employed generalized linear models (GLMMs) with Poisson error distribution (Crawley 2007). Because models of bird richness exhibited overdispersion $(\hat{\mathrm{c}}=3.98)$, we adjusted a negative binomial distribution. In all models, sites were included as a random effect. For identifying multicollinearity, we performed a correlation analysis. We did not exclude variables because the r coefficients were $<|0.7|$.

For the last objective, we assessed the proportions (duration of behavior in seconds/video length in seconds) of bird and mammal behaviors occurring more than twice. We fitted generalized linear models (GLMs) with Binomial error distribution (Crawley 2007). Because some fitted models exhibited overdispersion ( $\hat{c}>10)$, we fitted a quasibinomial model. The different behaviors were included as fixed variables.

We evaluate how well the model fits the data with diagnostic plots. For each model, a backward elimination procedure was used to remove insignificant variables without losing important information. All statistical analyses were carried out using R Core Team (2016).

\section{RESULTS}

The sampling of plants under the canopy of $R$. girolae yielded a list of 27 species (appendix 1). Species richness was estimated to be 28,31 and 30 by the Chao 2, Jackknife 1 and Jackknife 2 estimators, respectively. The observed number of species represented between 87 and $96 \%$ of the expected value. We recorded 11 species of birds (appendix 2). The estimated bird species richness was 12 (Chao 1 estimator). The observed number of species represented $92 \%$ of the expected value. Moreover, we recorded 12 mammal species (appendix 2). The estimated mammal species richness was 17, 18 and 21 (Chao 2, Jackknife 1 and Jackknife 2 estimators, respectively). The observed number of species represented between 57 and $70 \%$ of the expected value. The sample coverage was extended in the coverage-based rarefaction/extrapolation curve from 98, 94 and 92 to $100 \%$ for plant, bird and mammal species, respectively (figures 3A, 3B and 3C). We recorded 11 species of birds from among 63 individuals. The number of singletons was 11 , and the number of doubletons was four, yielding a coverage estimate of $83 \%(\mathrm{SE}=0.31 \%)$. Considering only the data from camera traps, we recorded eight species of mammals from among 65 individuals. The number of singletons was seven, and the number of doubletons was three, yielding a coverage estimate of $89 \%$ $(\mathrm{SE}=0.34 \%)$. The coverage deficit for birds and mammal species was 17 and $11 \%$, respectively. That is 17 and $11 \%$ of the birds and mammal individuals in the community belonged to species that were not detected by the sample. The camera traps captured two species never before recorded in Ischigualasto Provincial Park: brushland tinamou (Nothoprocta cinerascens Burmeister) and geoffroy's cat (Leopardus geoffroyi d'Orbigny et Gervais).

Species richness of plants and mammals was not explained by any of the variables included in the model (table 1). The best model explaining bird richness included number of stems arising from the main trunk with a significant effect and cover of shrubs with no significant effect 

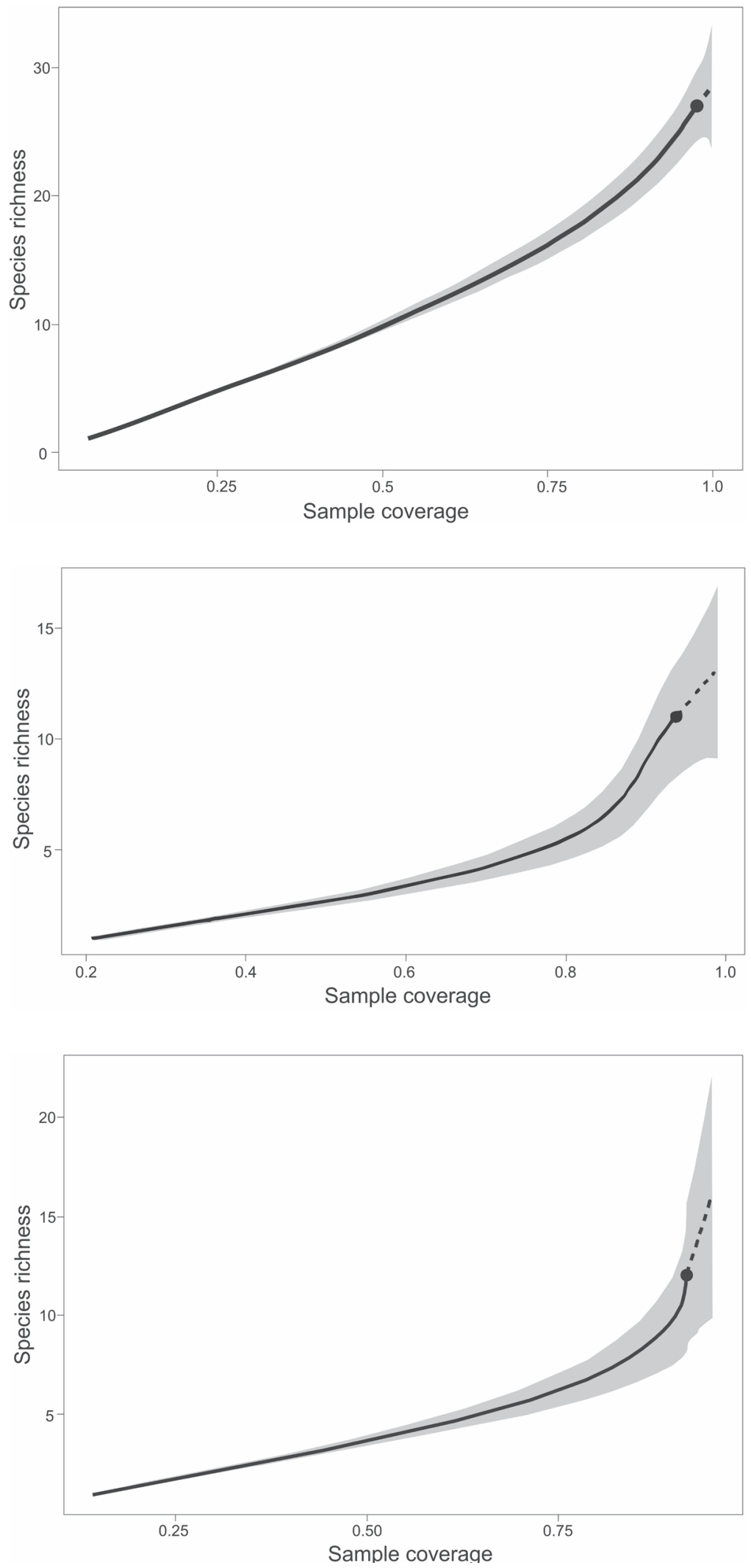

Figure 3. Coverage-based rarefaction/extrapolation curve (solid and dashed, respectively), with $95 \%$ confidence intervals (shaded areas, based on a bootstrap method with 200 replications), for (A) plant species, (B) bird species and (C) mammal species.

Curva de rarefacción/extrapolación basada en la cobertura (sólida y discontinua, respectivamente), con intervalos de confianza del $95 \%$ (áreas sombreadas, basado en un método bootstrap con 200 repeticiones), para las especies de (A) plantas, (B) aves y (C) mamíferos. 
(table 2). Based on this model, the odds for bird richness decreased by $\exp (-0.43)=0.65$, or $-43 \%$, for every unit increase in number of stems.

The native mammal species --Patagonian mara (Dolichotis patagonum Zimmermann), southern viscacha (Lagidium viscacia Molina) and guanaco (Lama guanicoe Müller)-- and the exotic mammal species --European hare (Lepus europaeus Pallas), feral donkey (Equus asinus Linnaeus) and cattle (Bos taurus Linnaeus)-- were only recorded from signs (appendix 1). Considering only the species of birds and mammals recorded by camera traps, four out of a total of 11 bird species and three out of a total of six mammal species occurred more than twice, thus they were considered for comparison of proportions of behaviors. We compared behaviors displayed by bird species (foraging and moving): spot-winged pigeon (Patagioenas maculosa Temminck), eared dove (Zenaida

Table 1. Mean and SE of morphological attributes of $R$. girolae and features of the habitat under its canopy.

Media y ES de los atributos morfológicos de Ramorinoa girolae y características del hábitat bajo su dosel.

\begin{tabular}{lrr}
\hline \multicolumn{1}{c}{ Attributes } & Mean & \multicolumn{1}{c}{ SE } \\
\hline $\begin{array}{l}\text { Morphological attributes } \\
\text { number of stems }\end{array}$ & 4.53 & 0.42 \\
maximum height $(\mathrm{m})$ & 4.84 & 0.31 \\
canopy area $\left(\mathrm{m}^{2}\right)$ & 443.30 & 102.39 \\
& & \\
Features of the habitat under canopy & & \\
cover of shrubs $(\%)$ & 26.74 & 4.21 \\
cover of herbs $(\%)$ & 2.58 & 0.65 \\
\hline
\end{tabular}

Table 2. The best model explaining bird richness considering morphological attributes of $R$. girolae and features of the habitat under its canopy $(\mathrm{df}=14)$. Parameter estimates $( \pm \mathrm{SE}), \mathrm{Z}$ and $P$ values for significance $(*=P<0.05 ; * *=P<0.01, * * *=P<$ $0.001, \mathrm{~ns}=$ no significant $)$.

El mejor modelo que explica la riqueza de aves considerando los atributos morfológicos de Ramorinoa girolae y características del hábitat bajo su dosel $(\mathrm{gl}=14)$. Parámetros estimados $( \pm \mathrm{ES})$, valores de $\mathrm{Z}$ y $P$ para significancia $\left({ }^{*} P<0,05 ; * * P<0,01,{ }^{*} * * P<0,001\right.$, ns $=$ no significativo).

\begin{tabular}{lccc}
\hline \multicolumn{1}{c}{$\begin{array}{c}\text { Explanatory } \\
\text { variable }\end{array}$} & $\begin{array}{c}\text { Parameter estimate } \\
\pm \mathrm{SE}\end{array}$ & $\begin{array}{c}\mathrm{Z} \\
\text { value }\end{array}$ & $\begin{array}{c}P \\
\text { value }\end{array}$ \\
\hline Intercept & $2.18 \pm 0.61$ & 3.56 & $* * *$ \\
Number of stems & $-0.43 \pm 0.17$ & -2.44 & $*$ \\
$\begin{array}{l}\text { Cover of shrubs } \\
\text { (percentage) }\end{array}$ & $0.03 \pm 0.02$ & 1.71 & $\mathrm{~ns}$ \\
\hline
\end{tabular}

auriculata Des Murs), crested gallito (Rhinocrypta lanceolata Geoffroy Saint-Hilaire) and rufous-collared sparrow (Zonotrichia capensis Müller); and mammal species (foraging, moving and resting): O. mimax, southern mountain cavy (Microcavia australis I. Geoffroy et d'Orbigny) and South American gray fox (Lycalopex griseus Gray, table 3). Although for bird species we found no differences between the proportions of behaviors displayed, all species invested more time (seconds) in foraging than in moving under the canopy $(P$. maculosa: foraging mean $=11.31 \pm \mathrm{SE}=$ 2.77 and moving $4.85 \pm 1.30 ; Z$. auriculata: foraging $8.83 \pm$ 2.66 and moving $3.67 \pm 1.92 ; R$. lanceolata: foraging 4.05 \pm 1.22 and moving $3.35 \pm 0.52 ; Z$. capensis: foraging 6.60 \pm 4.16 and moving $5.6 \pm 1.68)$. Octomys mimax displayed only foraging behavior. The time invested in foraging by $M$. australis was different from and higher $(11.81 \pm 1.79)$ than the time spent resting $(2.63 \pm 0.95, P=0.02)$ or moving $(3.84 \pm 0.96, P=0.04)$. Lycalopex griseus showed no differences in proportions of behaviors $(P>0.05$; foraging: 7.86 \pm 1.26 ; resting: $2.61 \pm 1.06$; moving: $4.18 \pm 0.87)$ though it invested more time in foraging than in other behaviors.

Table 3. Models to compare time invested in different behaviors, for bird (foraging and moving) and mammal species (foraging, moving and resting). Parameter estimates $( \pm \mathrm{SE}), \mathrm{T}$ and $P$ values for significance $(*=P<0.05 ; * *=P<0.01, * * *=P<0.001$, ns $=$ no significant).

Modelos para comparar el tiempo invertido en diferentes comportamientos, para aves (forrajeo y desplazamiento) y mamíferos (forrajeo, desplazamiento y descanso). Parámetros estimados ( \pm ES), valores de T y $P$ para significancia $(* P<0,05 ; * * P<0,01, * * * P<0,001$, ns $=$ no significativo).

\begin{tabular}{ccccc}
\hline Species & $\begin{array}{c}\text { Explanatory } \\
\text { variable }\end{array}$ & $\begin{array}{c}\text { Parameter } \\
\text { estimate } \pm \text { SE }\end{array}$ & T value & $P$ value \\
\hline \multirow{2}{*}{ P. maculosa } & intercept & $-0.50 \pm 0.46$ & -1.09 & $\mathrm{~ns}$ \\
& moving & $1.14 \pm 0.76$ & -1.50 & $\mathrm{~ns}$ \\
Z. auriculata & intercept & $-0.87 \pm 0.60$ & -1.45 & $\mathrm{~ns}$ \\
& moving & $-1.10 \pm 1.04$ & -1.06 & $\mathrm{~ns}$ \\
R. lanceolata & intercept & $-1.86 \pm 0.38$ & -4.86 & $* * *$ \\
& moving & $-0.22 \pm 0.56$ & -0.38 & $\mathrm{~ns}$ \\
\multirow{2}{*}{ Z. capensis } & intercept & $-1.27 \pm 0.88$ & -1.44 & $\mathrm{~ns}$ \\
& moving & $-0.21 \pm 1.28$ & -0.16 & $\mathrm{~ns}$ \\
& intercept & $-2.34 \pm 0.69$ & -3.38 & $* *$ \\
M. australis & foraging & $1.91 \pm 0.79$ & 2.42 & $*$ \\
& moving & $0.42 \pm 0.91$ & 0.47 & $\mathrm{~ns}$ \\
& intercept & $-2.35 \pm 0.63$ & -3.76 & $* * *$ \\
& foraging & $1.32 \pm 0.75$ & 1.76 & $\mathrm{~ns}$ \\
& moving & $0.53 \pm 0.81$ & 0.65 & $\mathrm{~ns}$ \\
\hline
\end{tabular}


Moreover, we assessed whether the abundance of the mesopredator $L$. griseus was affected by abundance of birds and abundance of small mammals as the gray leafeared mouse (Graomys griseoflavus Waterhouse), M. australis and O. mimax with GLMMs. We found that the abundance of this mesopredator increased with abundance of birds $(\mathrm{Z}=0.09, P=0.04, \mathrm{df}=15)$ nonetheless did not increase with abundance of small mammals $(\mathrm{Z}=0.26, P=$ $0.80, \mathrm{df}=16)$. Based on the first model, the odds for abundance of $L$. griseus increased by $\exp (0.09)=1.10$, or $9 \%$, for each bird individual added.

\section{DISCUSSION}

Among the main environmental services provided by woodlands, biodiversity conservation plays an important role in ecosystem functions, because biodiversity affects processes essential for human well-being. This is the first study to assess the role of $R$. girolae woodland in the provision of biodiversity-related ecosystem services. We recorded more than 80,90 and $50 \%$ of plant, bird and mammal species, respectively. The coverage estimate was 83 $\%$ for birds and $89 \%$ for mammals. Bird species richness decreased by $-43 \%$, for every unit increase in number of stems, though richness of plants and mammals was not explained by any variable considered. Birds tended to forage most of the time under the canopy of $R$. girolae, as also did $L$. griseus. In relation to rodents, we found that $O$. mimax only foraged and $M$. australis invested significantly more time in foraging than in moving or resting.

Our results showed high richness of plant species under the canopy of $R$. girolae; this tree species could influence the likelihood of seedling establishment by modifying physical environmental conditions. In arid and semiarid environments, woody plants are able to increase local soil fertility through accumulation of carbon and nitrogen and modification of the decomposition rate through increased infiltration rate, and through protection against high temperatures and radiation (Cesca et al. 2012). According to our data, Rossi and Villagra (2003) recorded high cover of shrub species under the canopy of mesquite (Prosopis flexuosa DC), probably because it generates spatial heterogeneity by modifying soil conditions, thus contributing to increasing total diversity of the ecosystem.

Camera-trapping furnishes an important noninvasive tool for estimating species presence and/or assessing patterns of abundance throughout space and time and their link with activity patterns, habitat use and reproductive information, which are key elements for wildlife conservation (Silveira et al. 2003). In our sampling, we recorded two species new to Ischigualasto Provincial Park, $L$. geoffroyi and $N$. cinerascens. Neither of these two species had been previously recorded for this protected area, although it is within their distribution areas. Leopardus geoffroyi is classified as Near Threatened because future population declines resulting from habitat conversion may result in its qualifying for Vulnerable (Lucherini et al. 2008). Nothoprocta cinerascens is a rare species with low probabilities of being observed (Lucero 2013). Moreover, we recorded between 57 and $70 \%$ of mammal richness, all species previously recorded for this area (Cortéz et al. 2010). Probably, other mammal species in this area do not use habitats under the canopy of $R$. girolae because they have different requirements from those offered by these trees. This assumption deserves further research because it can contribute to the knowledge and conservation of species associated with woodlands in deserts.

Bird species richness was negatively affected by number of stems arising from the main trunk. Previous studies comparing abundance of birds in creosote bush (Larrea cuneifolia Cav.) and mesquite woodland suggest that woodlands provide superior availability of suitable sites for spawning and feeding activities, with birds being more abundant in this habitat (Cueto et al. 2005). However, the stems of $R$. girolae are cylindrical, smooth and straight, with a sharp and relatively hard tip; probably due to these characteristics stems of this species are not suited as perches for birds. Another possible cause for this relationship is that the perceived risk of predation changes significantly with place and time due to variation in predator detectability, habitat structure and cover availability (Rodríguez et al. 2001), hence a high number of stems would hinder detection of and escape from predators. All registered bird species recorded occur in arid shrubland and woodland, and have ground-dwelling habits. Patagioenas maculosa, $Z$. auriculata and $Z$. capensis mainly consume seeds, whereas $R$. lanceolata is a skillful short flight runner that consumes larvae, insects, buds and small invertebrates obtained by digging the ground. We found a tendency of these species to invest more time in foraging, probably because they seek and find food under $R$. girolae canopy.

Large and medium mammals, such as B. taurus, E. asi$n u s$ and $L$. griseus, were the most frequently recorded under the canopy of $R$. girolae, however none of the variables considered in this work explained their presence. Probably, microclimate could be an important variable for $B$. taurus and $E$. asinus because we observed these species resting under the canopy at different times of the day ${ }^{1}$. Moreover, L. griseus, which is a generalist omnivore, spends most of its time foraging and its abundance increases with abundance of birds; therefore, probably availability of food, such as some bird species, is an important requirement for its habitat selection. For small mammals, like $O$. mimax and $M$. australis, the use of this tree species is probably related to fruit availability. Because $R$. girolae does not produce fruit every year ${ }^{2}, O$. mimax takes advantage of the availability of fruits and behaves as an opportunistic species, consuming and storing these fruits (Campos 2012). The fruits of $R$. girolae contain seeds of high nutritive value, though

\footnotetext{
Valeria E Campos. Personal observation
}

Valeria E Campos. Unpublished data. 
they are woody and very hard (Zapata et al. 2010). To date, $O$. mimax has been the only species observed to pierce fruits to remove the seeds (Campos 2012), however the camera traps captured M. australis manipulating fruits of $R$. girolae plants under their canopy as well. This is the first evidence of interaction between $R$. girolae fruits and $M$. australis.

The habitat under canopies of $R$. girolae is suitable for different species of shrubs, birds and mammals, allowing interactions among them. A high percentage of species could be captured by the camera traps, however probably more sampling time or specific sampling of birds, such as putting camera traps at different heights in trees plus birding, and of mammals, such as alive capture or footprints, would allow us to record more species. Anyway, this is the first study to assess the role of $R$. girolae in the provision of biodiversity-related ecosystem services. The records of native and/or endangered species allow us to know their current distribution and habitat requirements, consequently these records are key elements for the conservation of wildlife. Assessment of plant and animal species richness in woodlands is relevant to planning and management since their conservation can enhance biodiversity in arid ecosystems.

\section{ACKNOWLEDGEMENTS}

This research was supported by "Chica, Retamo and Algarrobo: important species for the conservation of Native Forest from Parque Provincial Ischigualasto and neighboring areas. Biological interactions, human activity effects and their mitigation". Native Forest Conservation Plan - National Act 26.331. We thank the staff of Ischigualasto Provincial Park for providing all the necessary facilities during fieldwork. Samples were processed in the Laboratory of the Institute and Museum of Natural Sciences (National University of San Juan). We acknowledge and are grateful for the help received from all the members of INTERBIODES (Interacciones biológicas del desierto), especially Flavio Cappa for his assistance on field. Nélida Horak assisted us in drafting the English version.

\section{REFERENCES}

Brockerhoff EG, H Jactel, JA Parrotta, SFB Ferraz. 2013. Role of eucalypt and other planted forests in biodiversity conservation and the provision of biodiversity-related ecosystem services. Forest Ecology and Management 301: 43-50.

Campos VE. 2012. Biología de Octomys mimax (Rodentia: Octodontidae): selección de hábitat y conservación en el Monte árido de San Juan. Biological Science Thesis. Córdoba, Argentina. Facultad de Ciencias Exactas, Físicas y Naturales. Universidad Nacional de Córdoba. 166 p.

Campos VE, FM Cappa, V Fernández Maldonado, SM Giannoni. 2016. Using remotely sensed data to model suitable habitats for tree species in a desert environment. Journal of Vegetation Science 27: 200-210.

Cesca E, PE Villagra, C Passera, JA Alvarez. 2012. Effect of Pro- sopis flexuosa on understory species and its importance to pastoral management in woodlands of the Central Monte Desert. Revista de la Facultad de Ciencias Agrarias UNCUYO 44(2): 207-219.

Colwell RK. 2011. Estimates: Statistical Estimation of Species Richness and Shared Species from Samples. Version 9. User's Guide and application. Consulted Aug. 2014. Available in http://purl.oclc.org/estimates

Cortéz E, SM Giannoni, CE Borghi. 2005. Fase II Plan de Manejo del Parque Provincial Ischigualasto. Período 2005-2010. San Juan, Argentina. Ente Autárquico del Parque Provincial Ischigualasto. $73 \mathrm{p}$.

Costa G. 1995. Behavioural adaptations of desert animals. New York, USA. Springer-Verlag. 198 p.

Crawley MJ. 2007. The R book. London, England. John Wiley and Sons. 942 p.

Cueto VR, J Lopez de Casenave, MC Sagario, J Damonte. 2005. Relación aves-vegetación: importancia de los algarrobales para la avifauna del desierto del Monte. In Brown A, U Martínez Ortiz, M Acerbi, J Corcuera eds. La Situación Ambiental Argentina 2005. Buenos Aires, Argentina. Fundación Vida Silvestre Argentina. p. 234-236.

García D, R Zamora, GC Amico. 2011. The spatial scale of plantanimal interactions: effects of resource availability and habitat resource. Ecological Monographs 81(1):103-121.

Hadad M, M Almirón, J Scaglia. 2014. Estructura de un bosque de Ramorinoa girolae (Fabaceae), en la Sierra de Pie de Palo, San Juan (Argentina). Sociedad Argentina de Botánica 49(2): 283-292.

IUCN (International Union for Conservation of Nature and Natural Resources, UK). 2001. 2001 IUCN Red List Categories and Criteria version 3.1. Available in http://www.iucnredlist.org/technical-documents/categories-and-criteria/2001categories-criteria

Labraga JC, R Villalba. 2009. Climate in the Monte Desert: Past trends, present conditions, and future projections. Journal of Arid Environments 73(2):154-163.

Lucero F. 2013. Listado de las aves observadas en la Reserva Natural Municipal articulada: Laguna de Guanacache, Laguna del Toro y Bañados del Carau, provincia de San Juan, y Laguna Seca y los Bañados del Tulumaya, provincia de Mendoza, Argentina. Parte II. Nótulas Faunísticas (Segunda Serie) 137: 1-16.

Lucherini M, T de Oliveira, G Acosta. 2008. Leopardus geoffro$y i$. The IUCN Red List of Threatened Species. Versión 2014.3. Consulted Sep. 2015. Available in http://www.iucnredlist.org.

Márquez J, E Martínez Carretero, A Dalmasso, G Pastrán, G Ortiz. 2005. Las áreas protegidas de la provincia de San Juan (Argentina) II. La vegetación del Parque Provincial de Ischigualasto. Multequina 14(1): 1-25.

Martin P, P Bateson. 1993. Measuring behaviour. An Introductory Guide. Cambridge, UK. Cambridge University Press. 222 p.

Millennium Ecosystem Assessment (MEA). 2005. Ecosystems and Human Well-being: Biodiversity Synthesis. Washington, DC, USA. World Resources Institute. 86 p.

Papú S. 2014. Caracterización general y depredación predispersiva en poblaciones de Chica (Ramorinoa girolae) del Parque Provincial Ischigualasto (San juan, Argentina). Degree Seminars. Mendoza, Argentina. Facultad de Ciencias Agrarias, Universidad Nacional de Cuyo. 76 p. 
R Core Team. 2016. R: A language and environment for statistical computing. R Foundation for Statistical Computing. Vienna, Austria. Consulted Sep. 2016. Available in https:// www.R-project.org/

Rodríguez A, H Andrén, G Jansson. 2001. Habitat-mediated predation risk and decision making of small birds at forest edges. Oikos 95(3): 383-396.

Rossi BE, PE Villagra. 2003. Effects of Prosopis flexuosa on soil properties and the spatial pattern of understorey species in arid Argentina. Journal of Vegetation Science 14(4):543-550.
Silveira L, ATA Jácomo, JAF Diniz-Filho. 2003. Camera trap, line transect census and track surveys: a comparative evaluation. Biological Conservation 114(3): 351-355.

Thompson I. 2011. Biodiversidad, umbrales ecosistémicos, resiliencia y degradación forestal. Unasylva 238(62): 25-30.

Zapata R, PR Quiroga, NR Grosso. 2010. Valoración química de las semillas de Ramorinoa girolae Speg. "chica" para la alimentación humana. In CIEFAP ed. Congreso Eco Productos Forestales No Madereros. 1-3 de diciembre de 2010. Esquel, Argentina. p. 149.

Recibido: 22.11.16

Aceptado: 19.02.17

Appendix 1. Plant species recorded under the canopy of $R$. girolae and their relative frequency.

Especies de plantas bajo la copa de Ramorinoa girolae.

\begin{tabular}{|c|c|c|}
\hline Family & Species & Relative frequency (\%) \\
\hline Asteraceae & Cyclolepis genistoides Gillies ex D.Don. & 4.24 \\
\hline Bromeliaceae & Tillandsia sp. L. & 8.48 \\
\hline Cactaceae & $\begin{array}{l}\text { Cereus sp. Mill. } \\
\text { Echinopsis sp. Zucc. } \\
\text { Echinopsis terscheckii (J.Parm. ex Pfeiff.) H.Friedrich et G.D.Rowley. } \\
\text { Gymnocalycium sp. Pfeiff. ex Mittler. } \\
\text { Opuntia sulphurea G.Don. } \\
\text { Tephrocactus } \text { sp. Lem. }\end{array}$ & $\begin{array}{l}1.82 \\
5.45 \\
1.21 \\
2.42 \\
4.85 \\
2.42\end{array}$ \\
\hline Capparaceae & Capparis atamisquea Kuntze. & 10.91 \\
\hline Chenopodiaceae & Atriplex sp. L. & 0.61 \\
\hline Celastraceae & Maytenus viscifolia Griseb. & 5.45 \\
\hline Ephedraceae & Ephedra triandra Tul. & 1.21 \\
\hline Fabaceae & $\begin{array}{l}\text { Cercidium praecox (Ruiz et Pav. ex Hook. et Arn.) Harms. } \\
\text { Geoffroea decorticans (Gillies ex Hook. et Arn.) Burkart. } \\
\text { Mimosa ephedroides Benth. } \\
\text { Prosopis flexuosa DC. } \\
\text { Prosopis torquata DC. } \\
\text { Senna aphylla (Cav.) H.S. Irwin et Barneby. } \\
\text { Zuccagnia punctata Cav. }\end{array}$ & $\begin{array}{l}2.42 \\
3.03 \\
0.61 \\
1.21 \\
5.45 \\
3.03 \\
6.06\end{array}$ \\
\hline Lamiaceae & Salvia cuspidata Ruiz et Pav. & 0.61 \\
\hline Loranthaceae & Ligaria cuneifolia Tiegh. & 1.21 \\
\hline Poaceae & Pappophorum sp. Schreb. & 4.24 \\
\hline Plantaginaceae & Monttea aphylla (Miers) Benth. et Hook. & 2.42 \\
\hline Solanaceae & $\begin{array}{l}\text { Grabowskia obtusa Arn. } \\
\text { Lycium sp. L. }\end{array}$ & $\begin{array}{l}0.61 \\
9.09\end{array}$ \\
\hline Zygophyllaceae & $\begin{array}{l}\text { Bulnesia retama (Gillies ex Hook. et Arn.) Griseb. } \\
\text { Larrea cuneifolia Cav. }\end{array}$ & $\begin{array}{l}1.21 \\
9.70\end{array}$ \\
\hline
\end{tabular}


Appendix 2. Bird and mammal species recorded under the canopy of $R$. girolae, relative frequency (\%) and type of record (camera traps or signs such as feces, footprints, caches of plant material).

Especies de aves y mamíferos registrados bajo la copa de Ramorinoa girolae. Se muestra la frecuencia relativa de cada especie, y el tipo de registro (cámara trampa o signos como heces, huellas, restos de material vegetal).

\begin{tabular}{|c|c|c|c|c|c|}
\hline \multirow[b]{2}{*}{ Family } & \multirow[b]{2}{*}{ Species } & \multirow[b]{2}{*}{ Common name } & \multirow{2}{*}{$\begin{array}{l}\text { Relative } \\
\text { frequency }\end{array}$} & \multicolumn{2}{|c|}{ Recorded by } \\
\hline & & & & $\begin{array}{c}\text { camera } \\
\text { traps }\end{array}$ & signs \\
\hline \multicolumn{6}{|l|}{ Birds } \\
\hline \multirow{2}{*}{ Columbidae } & Patagioenas maculosa Temminck & spot-winged pigeon & 22.22 & $\mathrm{X}$ & \\
\hline & Zenaida auriculata Des Murs & eared dove & 12.70 & $\mathrm{X}$ & \\
\hline Thraupidae & Saltator aurantiirostris Vieillot & golden-billed saltator & 1.59 & $\mathrm{X}$ & \\
\hline Emberizidae & Zonotrichia capensis Müller & rufous-collared sparrow & 12.70 & $\mathrm{X}$ & \\
\hline \multirow{2}{*}{ Furnariidae } & Furnarius cristatus Burmeister & crested hornero & 3.17 & $\mathrm{X}$ & \\
\hline & Pseudasthenes steinbachi Hartert & chestnut canastero & 1.59 & $\mathrm{X}$ & \\
\hline Mimidae & Mimus saturninus Lichtenstein & chalk-browed mockingbird & 1.59 & $\mathrm{X}$ & \\
\hline Rhinocryptidae & Rhinocrypta lanceolata Geoffroy Saint-Hilaire & crested gallito & 36.51 & $\mathrm{X}$ & \\
\hline \multirow{2}{*}{ Tinamidae } & Eudromia elegans Saint-Hilaire & elegant crested-tinamou & 3.17 & $\mathrm{X}$ & \\
\hline & Nothoprocta cinerascens Burmeister & brushland tinamou & 3.17 & $\mathrm{X}$ & \\
\hline Tyrannidae & Elaenia albiceps d'Orbigny et La-fresnaye & white-crested elaenia & 1.59 & $\mathrm{X}$ & \\
\hline \multicolumn{6}{|l|}{ Mammals } \\
\hline Bovidae & Bos taurus Linnaeus & cattle & 22.95 & & $\mathrm{X}$ \\
\hline Camelidae & Lama guanicoe Müller & guanaco & 1.64 & & $\mathrm{X}$ \\
\hline Canidae & Lycalopex griseus Gray & south American gray fox & 21.31 & $\mathrm{X}$ & $\mathrm{X}$ \\
\hline \multirow{2}{*}{ Caviidae } & Microcavia australis I. Geoffroy et d'Orbigny & southern mountain cavy & 6.56 & $\mathrm{X}$ & $\mathrm{X}$ \\
\hline & Dolichotis patagonum Zimmermann & Patagonian mara & 1.64 & & $\mathrm{X}$ \\
\hline Cricetidae & Graomys griseoflavus Waterhouse & gray leaf-eared mouse & 4.92 & $\mathrm{X}$ & \\
\hline Equidae & Equus asinus Linnaeus & feral donkey & 19.67 & & $\mathrm{X}$ \\
\hline Felidae & Leopardus geoffroyi d'Orbigny et Gervais & Geoffroy's cat & 1.64 & $\mathrm{X}$ & \\
\hline \multirow{2}{*}{ Leporidae } & Lepus europaeus Pallas & European hare & 9.84 & & $\mathrm{X}$ \\
\hline & Lagidium viscacia Molina & southern viscacha & 1.64 & & $\mathrm{X}$ \\
\hline Mephitidae & Conepatus chinga Molina & Molina's hog-nosed skunk & 1.64 & $\mathrm{X}$ & \\
\hline Octodontidae & Octomys mimax Thomas & viscacha rat & 6.56 & $\mathrm{X}$ & $\mathrm{X}$ \\
\hline
\end{tabular}

